\title{
Yazılı Basındaki Siyasi Haberlerin Ekonomik Bağlamı
}

\author{
The Economic Context of Political News in Print Media
}

\author{
Fırat Ata ${ }^{1 *}$ (i) Cihan Çakır ${ }^{2}$ (ic) \\ ${ }^{1}$ Department of Journalism, Hatay Mustafa Kemal University, Hatay, Turkey \\ 2 PhD Student, Department of Journalism, Selçuk University, Konya, Turkey
}

\begin{abstract}
Received: 09.11.2021
Accepted: 29.12 .2021

This article was checked by intihal.net

\section{Öz}

Geleneksel ve dijital versiyonlarıyla insanların genel bilgi alma kaynaklarından biri olan medya, "eğlence, boş zaman geçirme, toplumsal farkındalık sağlama" gibi birçok işleve sahiptir. Medya, belirtilen işlevleri yerine getirirken temelde haber unsurunu kullanmaktadır. Haber metinlerinin yazı Iması ve yayınlanması aşamalarında birçok etki/kontrol mekanizması devreye girmektedir. Medya kuruluşları, ekonomik-politik anlamda yakın ilişkide olduğu kurum ve kuruluşlara karşı eleştirel haber yapmakta çekinmektedir. Haberciliğin temel işlevlerinden biri olan bilgi verme süreci belirtilen bu kaygı sebebiyle sekteye uğramaktadır. İçerik Çözümlemesi yönteminin kullanıldığı bu çalışma kapsamında yazıı basın örneklerinden biri incelenmiştir. Medya, ekonomi ve siyaset kurumları arasındaki ilişki hakkında bilgi vermeyi amaçlayan bu çalışmada elde edilen literatür taraması verileri uygulama bulgularıyla örtüşmektedir. Diğer bir ifadeyle elde edilen bulgular, belirtilen üç kurum arasında net bir ilişkinin varlığını ve medya içeriklerinde ekonomik-politik ilişkilerin belirleyici olduğunu göstermektedir. Medya kuruluşlarının, bu tarz ekonomik-politik etkiler/baskılar altında kalmaması için kendine özgü gelir modellerini geliştirmesi ve medyanın ve medya içeriklerinin üzerindeki kontrol baskısının azalmasına katkı sağlayacaktır.
\end{abstract}

Anahtar Kelimeler: Geleneksel Medya, Yazılı Basın, Ekonomi-Politik, Iç̧erik Çözümlemesi.

\section{Abstract}

The media, which is one of the sources of general information for people with its traditional and digital versions, has many functions such as "entertainment, leisure time, social awareness". The media mainly uses the news element when performing the specified functions. Many mechanisms of influence/control come into play at the stages of writing and publishing news texts. Media organizations are reluctant to make critical news against institutions and organizations with which they have a close economic and political relationship. Within the scope of this study, in which the Content Analysis method is used, one of the examples of the written press is examined. The literature review data obtained in this study, which aims to provide information about the relationship between media, economy and political institutions, overlaps with the application findings. In other words, the findings show that there is a clear relationship between the three mentioned institutions and that the economic-political relations are determinant in the media contents. It will contribute to the reduction of the pressure of control over the media and media contents, and the development of their own revenue models in order for media organizations not to be under such economic-political influences/pressures.

Keywords: Traditional Media, Printed Media, Economy-Politics, Content Analysis.

Ata, F. \& Çakır, C. (2021). Yazılı Basındaki Siyasi Haberlerin Ekonomik Bağlamı. Journal of Academic Value Studies, 7(4), 503-514. http://dx.doi.org/10.29228/javs.54125

\footnotetext{
*E-mail address: firatata47@gmail.com (Corresponding Author)
} 


\section{Giriş}

Toplumsal kurum, toplumun varlığını koruyabilmesi için meşru olanı ve olmayanı tanımlayan, zorlayıcılığı, tutarlılığı ve göreli bir sürekliliği bulunan kurallar ve ilişkiler bütünüdür. Aile, din, eğitim, medya, hukuk, siyaset ve ekonomi önemli toplumsal kurumlardır. Toplumsal kurumlar, insanların bir arada yaşamaya başlamalarıyla ortaya çıkmıştır. Belirli gereksinimleri karşılamaya yönelik olan ilişkiler sıklıkla yinelendikçe, süreklilik ve tutarılık kazanmaya, herkesi kendine uymaya zorlayan, inanç ve davranış kalıplarına dönüşmüştür. Toplumsal kurumlar, toplumu biçimlendirir, toplumsal düzenin sürmesi için uyulması gerekli kuralları ve ilişki kalıplarını ortaya koymaktadır (Kışlalı, 1999: 91-92).

Medya, siyaset ve ekonomi de önemli toplumsal kurumlar olarak birbirini etkileyen/birbirinden etkilenen yapıdadırlar. Siyaset, toplumsal dinamikler arasında yönetim fonksiyonlarını içeriğinde barındırdığı için önem arz etmektedir. Diğer bir ifadeyle siyaset diğer tüm toplumsal dinamikleri doğrudan etkileyebilme potansiyeline sahiptir. Siyaset gibi ekonomi kurumu da insanların ve/veya kuruluşların hayatlarını/devamlılı̆ını sağlayabilmesi açısından temel bir gereklilik olarak belirmektedir. Siyaset ve ekonominin etkilediği kurumlardan biri olan medyaysa belirtilen alanlardaki değişim ve dönüşümleri kamuoyuna duyurma işlevine sahiptir. Geniş kitlelere ulaşma potansiyeli olan medya, bu yönüyle siyaset ve ekonomi gibi kurumların ilgilendiği ilk alanlardan/araçlardan biri olmaktadır. Dolayısıyla belirtilen ilişkiler medya, siyaset ve ekonomi kurumları arasında yakın bir bağ kurulmasını sağlamaktadır. Oluşan yakın bağın medya açısından artıları olduğu gibi bu bağ medyanın en önemli içeriklerinden biri olan haber metinlerinin gerçeklik, doğruluk ve güvenirlilik gibi temel parametrelerine zarar da verebilmektedir.

Kaya'nın da belirttiği gibi medya kurumu, yapısı gereği siyaset, ekonomi ve diğer toplumsal kurumlarla karşılıklı etkileşim halindedir. Medya sektörü, özünde ticari- sanayi bir etkinliktir. Medya, kendisinin de yer aldığı genel toplumsal sistem içerisinde; bu bağlamı oluşturan toplumsal-siyasal-ekonomik güç ilişkilerinin eklemlenmesi çerçevesinde oluşmaktadır (1999: 23). Medya bir yandan siyaset ve ekonomi kurumları üzerinden devamlılı̆ını sağlarken, ekonomi ve siyaset kurumları da medyayı bir araç olarak kullanarak hedef kitleye ulaşmaktadır (Arabacı, 2004: 105).

Siyasal toplumsallaşma sürecinde önemli rollerden birini oynayan medya, siyasal yönelimlerin şekillendiricisi niteliğindeki önemini arttırmaktadır. Bu durum, hem seçmenler tarafından hem de seçilenler tarafından bilinmekte ve kabul görmektedir (Yüksel, 2004: 261). Medya ve siyaset günümüzde birbirinden ayrılamayan iki kavramdır. Medya ve siyasetin içeriği karşılıklı belirleme ilişkisi içinde tanımlanabilir (Yaşın, 2013: 3). Medyayla siyasi ve toplumsal çevre arasında karşııkı bağımlılık esasına dayanan semiyotik bir ilişki bulunmaktadır. Medya, maddi nedenler ve ham madde ihtiyacı nedeniyle siyasi ve toplumsal dinamiklere yakın durmaktadır (Arslan, 2004: 1). Medya, haberlerin ve çözümlemelerin çatısını yerleşik ayrıcalıkları destekleyen bir çerçevede kurarak ve bu doğrultuda her türlü tartışmayı sınırlayarak, birbirleriyle sıkı sıkıya kaynaşmış olan devletin ve şirketlerin çıkarlarını ön plana çıkarabilmektedir. Böylece, kitle iletişim araçlarının içerikleriyle mesajlarının taşıdığı anlamlar esas olarak içinde üretildikleri örgütün ekonomik temeliyle belirlenmektedir (Chomsky, 1993: 23).

Medya kuruluşlarının siyaset ve ekonomi kurumlarıyla olan ilişkisini kesmesi günümüz gerçekliğinde mümkün değildir. Dolayısıyla medya kuruluşlarının siyaset ve ekonomi kurumlarıyla olan ilişkisini tamamen koparmak yerine gazetecilik/habercilik etiği kapsamında gözden geçirmesi gerekmektedir. Siyaset ve ekonomi kurumlarının gerçekliği medya metinlerini şekillendirmemeli; medya da temel işlev ve özelliklerine uygun olarak habercilik sorumluluklarını öncelik edinmelidir. Toplumsal hayat içerisindeki üç temel dinamiği konu edinen bu çalışma, yukarıda ifade edilenler doğrultusunda medya, siyaset ve ekonomi kurumları arasındaki ilişkiye yönelik bir literatür taramasını ve geleneksel yayıncılık yapan bir gazeteye yönelik bir içerik çözümlemesini içermektedir. ỉki bölümden oluşan çalışmada öncelikle medya, siyaset ve ekonomi kurumlarına yönelik teorik bilgiler verilmiştir. Belirtilen kurumlarla ilgili verilen temel bilgiler sonrası medya, siyaset ve ekonomi kurumları arasındaki ilişki açıklanmıştır. Teorik bilgilerin yanı sıra ilgili gazete örneğinde elde edilen bulgular ve bu bulgulara ait yorumlar, çalışmanın ikinci bölümünü oluşturmaktadır. Çalışma, genel bir değerlendirmeyi içeren sonuç bölümüyle tamamlanmaktadır.

\section{Medya, Ekonomi ve Siyaset Kurumları Arasındaki Ilişki}

Gazete, televizyon, internet gibi mesajın kitlelere ulaşmasını sağlayan kitle haberleşme araçlarının, eş deyişle yazılı, sözlü ve görüntülü kitle iletişim araçlarının tamamı medya kavramı içinde bir araya getirilmektedir (Yüksel, 2004: 28). Medya, kitle iletişim araçlarının tümüdür. Kitle iletişim araçları, kısmen beceri, kısmen sanat, kısmen de bilimdir (Bülbül, 2001: 2; Severin ve Tankard, 1994: 4). Medyanın giderek etki alanını genişletmesi ve insan yaşamının hemen her alanına ve anına nüfuz etmesi ile birey/toplum üzerindeki etkisi de artmaktadır. Günümüzde medya, yeniden üreten, 
şekillendiren, yöneten, kontrol eden bir iktidar aracına dönüşmüştür (Mora, 2008: 78). Turan'a (1994: 45) göre de medya, herhangi bir konudaki enformasyonu kısa zamanda geniş kitlelere yayabildiği için gündelik hayatta etkili olmaktadır.

Tokgöz'e göre kitle iletişim araçları, toplumun iletişimin yapısı içinde merkezi bir konuma sahiptir (2000: 109). Toplumsal bir iletişim kurumu olması nedeniyle medya, sözcüsü olduğu toplumun ilerlemesinde ya da geri kalmasında önemli bir role sahiptir ve bu kamusal görev, toplumsal dinamiklerin bel kemiğini oluşturmaktadır (Gürcan ve Yüksel, 2005: 6). Diğer bir ifadeyle medya, halk ile yönetenler arasında bağlantı kurması, diyalog sağlaması ve diğer işlevlere sahip olması açısından önem arz etmektedir (içel, 1990: 95).

Liberal/çoğulcu görüşlere göre, medyanın beş temel işlevi vardır. Bunlar; "bilgilendirme, kültürel devamlılık, toplumsallaştırma, kamuoyu yaratma, eğlendirmedir." Eleştirel bakış açısına göreyse medyanın işlevi, ekonomik sistemin ve bilinç yönetiminin satışını yapmaktır. Bunu medya ürünlerini dolayımlayarak ya da reklâm ve ilanların sunumuyla birlikte yapmaktadır. Medya ürünleri, egemen güç/iktidarın ve egemen kültürün devamını sağlamaya ve meşru kılmaya yönelik anlayışla üretilirler. Küreselleşme ile birlikte kültürel emperyalizm, medya üzerinden yürütülmektedir (Mora, 2008: 94). Medyanın en temel işlevi haber vermesidir. Haber, gazeteciliği meslek edinmiş kişilerin, haber konusu olarak seçtikleri konularda topladıkları ve kuralına göre formatladıkları, yine gazeteciliği meslek edinmiş kitle iletişim araçlarının sorumluları tarafından seçilerek yazılı, sesli ya da görüntülü mesajlar şeklinde okuyucuya, dinleyici ya da izleyiciye ulaştırılan bilgilerdir (Yüksel, 2004: 229; Aslan, 2002: 118). Medya haber verme işleviyle topluma çeşitli girdileri, olgular ve değer yargıları arasında çeşitli bağlantılar kurarak sunmaktadır. Bu sunuş sırasında gördükleri toplumsal işlevler yanında bazı psiko-sosyal işlevleri de yerine getirmektedir (Tokgöz, 2000: 7).

Medya organlarının insanları eğlendirmek, eğitmek ve bilgilendirmek gibi birçok işlevi bulunmaktadır. Çevrelerinde olup biten olaylar hakkında bilgi almak, boş zamanlarını iyi geçirmek için eğlence programlarını seyretmek, ülke ve dünya ekonomisinde olup bitenleri öğrenerek birikimlerine yön vermek gibi insanları yakından ilgilendiren konuları işleyen medya organları verdikleri siyasi haberlerle de ülke yönetimi hakkında çoğu zaman söz sahibi olabilmektedir. Demokrasilerin olmazsa olmazı, yasama yürütme ve yargı organlarından sonra kendinden dördüncü güç olarak bahsettiren medya organları toplumun gündemini oluşturmak için birçok habere imza atmaktadır (Şimşek, 2009: 125). Özetlemek gerekirse haberlerin yerine getirdikleri işlevleri, "bilgilendirme, toplumsallaştırma, güdüleme, tartışma ortamı yaratma, eğitim, kültürün gelişmesine katkı, eğlendirme, toplumsal bütünleştirmeyi yerine getirme" başlıkları altında toplamak mümkündür (Gürcan ve Yüksel, 2005: 7). Medya kurum ve kuruluşları, bu işlevleri yerine getirirken bazı sorumluluklara sahiptir. Bunların başında medya çalışanlarının, çalışı̆̆ğı basın, yayın kuruluşuna sorumluluğunu içeren hiyerarşik sorumluluk, medyanın, toplumun istek ve beklentilerine karşı sorumluluğu ve medya çalışanlarının kendilerine karşı bireysel sorumluğu gelmektedir (Bülbül, 1994: 63). Medya da birçok toplumsal kurum gibi ekonomiyle iç içedir. Ekonomi, gelir-gider dengesinin yanı sıra medyayı ve medya içeriklerini doğrudan ve/veya dolaylı olarak etkilemektedir.

Ekonomi, bir toplumda sınırlı kaynakların, sınırsız ihtiyaçların karşılanmasında azami faydayı veya tatmini sağlayacak şekilde kullanımasını ve böylece ihtiyaçlarla kaynaklar arasında ortaya çıkan temel iktisadi sorunun çözümünü araştıran bir bilim dalıdır (Yiğitbaşı ve Atabey, 2001: 1). Başka bir deyişle, ekonomi üretim ile tüketim veya arz ve talep arasında dengenin nasıl oluştuğunu ve üretim faktörlerinin nasıl kullanıldığını inceleyen bir bilim dalı olarak tanımlanmaktadır (Ülgen, 2002: 3).

Ekonomi kurumu, her ülkenin sosyal-ekonomik yapısına, halkının davranış biçimlerine ve yürürlükteki hukuki sistemin etkinliğine bağlı olarak ortaya çıkan ekonomik çerçeveyi ifade etmektedir (Eski, 1995: 34). Ekonomi kurumları, bir toplumda yaşamın aksamadan yürümesi için ne gibi bir yapılaşmaya gerek olduğunu çözmeye çalışmaktadır. Bunu sağlamak için de kendine ait kuralları ve karar alma birimleri bulunmaktadır (Şahin, 1997: 27). Toplumlar seçmiş oldukları ekonomik sistemler içinde kaynakları kullanarak kişi ihtiyaçlarını karşılamak için mal ve hizmet üretmektedir. Her ekonomik kurum/sistem, ayrı üretim kuralları içinde çalışmakta, ayrı bir biçimde örgütlenmiş mal ve hizmetlerin dağılımını da kendine özgü kurallara bağlamaktadır (Ünlüönen ve Tayfun, 2005: 33).

Üç farklı ekonomik sistem bulunmaktadır. Kapitalist sistem, özel teşebbüse ve piyasa serbestliğine dayanan üretim sistemi olarak tanımlanan ve özel mülkiyet ile iktisadi hürriyete dayanan piyasa ekonomisidir. Sosyalist sistem, karar organın hazırladığı planlara göre yürütülen toplumun her şeyin üstünde tutulmasına öngören sistemdir. Karma ekonomi sistemde ise, iktisadi toplumun temel meselelerinin çözümünde piyasa mekanizması esas alınmakla birlikte bu mekanizmaların toplum menfaatlerine aykırı olarak işlemesine yönelik tedbirler söz konusu olmaktadır (Demirci vd., 2001: 75-82). Ekonomi kurumuna ihtiyaç, insanların topluluk halinde yaşamalarından ve iş bölümüne ve uzmanlaşmaya 
gitmelerinden kaynaklanmaktadır. Günümüz toplumlarında iş bölümü, uzmanlaşma ve daha fazla pay almak için rekabeti ileri boyutlara ulaşmış olduğundan bireylerin toplum içindeki iktisadi faaliyetlerini iyi bir şekilde organize etmek meselesi önem kazanmaktadır (Şahin, 1997: 27).

Ekonomi kurumunda yer alan temel kavramları şu şekilde özetlemek mümkündür: İhtiyaç, tatmin edildiği zaman haz, tatmin edilmediği zaman ıstırap veren bir duygudur. İtiyaçların tatmini için insanlar mal ve hizmetleri satın almaktadır (Özgüven, 1975: 5). Mal, insanların maddi ihtiyaçlarını gideren fiziki varlıklar iken, hizmet, belirli ihtiyaçları gidermesine rağmen fiziki varlığı olmayan malları ifade etmektedir (Şimşek ve Aydın, 2002: 20). intiyaçların bir mal veya hizmetle giderilmesi fayda kavramını doğurmaktadır. Bir faydanın yaratılabilmesi için hammaddeye değer katma süreci üretim ile (Altınok, 2002: 15-16), insanların intiyaçlarını doğrudan doğruya giderilmesini sağlayacak mal ve hizmetlerin kullanılması ise tüketim kavramıyla belirtilmektedir (Özgüven, 1975: 6). Üretim ve tüketim ilişkilerinin yani herhangi bir malın ya da faktörün alıcıları ile satıcılarının karşı karşıya geldiği ve fiyatlarının belirlendiği ortama piyasa denmektedir (Şimşek ve Aydın, 2002: 23). Malların para ile olan ifadesi de fiyat olarak adlandırılmaktadır (Eski, 1995: 13). Bir malın ve hizmetin değeri, tüketicilerin o mala veya hizmete verdikleri önemdir. Bu önem büyük ölçüde toplumda değişim ve ödeme aracı olarak kullanılan genel kabul gören, kendi dışındaki tüm ekonomik varlıkların değerini ölçmeye yarayan para aracıyla gösterilmektedir (Ünlüönen ve Tayfun, 2011: 13, 14). Para miktarının, mal üretimine ve arzına oranla aşırı bir artış göstermesi fiyatların genel seviyesinin yükselmesi enflasyon, enflasyon olaylarının tersi, yani para miktarı ve kredi hacminin daralarak ekonomide durgunluğa neden olması deflasyon olarak adlandırılmaktadır. Hem enflasyon hem de deflasyonun aynı anda yaşanması stagflasyon kavramı ile ifade edilmektedir. Devalüasyon, bir ülkenin para biriminin kıymetini yabancı paralara nazaran düşürmekken revalüasyon, milli paranın kanuni kıymetinin devletçe artırılmasıdır (Demirci vd., 2001: 259-262).

Gezgin'e (2014: 168) göre medyanın ekonomik bir oluşum olduğunu açıklayan en güzel örnek şu alıntıdır: “Hangi devir olursa olsun, gazete sorumluları şu üç hedefi izlemektedir. Basılacak metnin miktarını arttırmak (sayfa sayısı ve tiraj olarak); çeşitlilik ve içeriğin zenginleştirilmesi (metinler, grafikler, fotoğraflar); üretim maliyetlerinin sürekli düşürülmesi (satış fiyatını dengede tutmak ve düşürmek için)". Görüldüğü üzere gazete için yapılan bu hedefler, aslında medyanın ekonomik oluşumu niteliğini açıklamaktadır (Gezgin, 2014: 168). Bu ekonomik yapının işleyişi, kesintisiz ve hızlı bir haber ve enformasyon akışını zorunlu kılmaktadır. Bunu da dünyayı saran iletişim ağları üzerine kurulmuş, yani bilgi çağının iletişim ve haberleşme araçları/medya yerine getirmektedir (Özçağlayan, 2014: 153). Medyanın ekonomik boyutuna ilişkin değerlendirmeleri detaylandırmak mümkündür. Ancak her ne kadar medya doğrudan ticari bir araç olarak görülmese de, ticari bir sürecin ya doğrudan ya da dolaylı önemli bir aktör niteliğindedir. Tüm süreçleri açısından çok açık biçimde bir ekonomik oluşumu ifade etmektedir. Her ekonomik oluşum gibi sürekliliğini ve devamlılığını sağlamak için karlıı̆̆ını ve verimliliğini sürdürmek zorundadır (Gezgin, 2014: 169).

Medya ekonomisi, içinde bulunduğu siyasal ekonomik koşulların biçimlendirdiği bir kitle iletişim araçları üretimine dayanmaktadır. Doğası gereği kitle iletişim araçları da içinde bulunduğu siyasal ekonominin ve üretim ilişkileri sürecinin biçimlendirmesiyle üretimlerini yaparlar. Bilinç yönetimi işinden ekonomik değer yaratır ve egemen üretim ilişkileri sürecini beslerler. Yine üretilen her ürün, üretim ilişkileri sürecinin etkisi altındadır. Bu etkiler medya ürünü üzerinde; ürün üzerindeki mülkiyet ilişkilerinin biçimi (1), üretim sürecine katılanların ekonomik nitelikteki beklentileri (2), tüketicilerinin ürüne karşı oluşturdukları tüketim davranışları (3), üretim girdilerinin maliyeti ve ürünün meta olarak değişim değerine göre (4) belirleyici olmaktadır. Bütün bu etkenlerin uygulamadaki etkilerine göre, üretim sürecine katılanlar arasındaki egemen ilişki konumları değişmekte, medya ürününün gerek içerik gerekse tüketim biçimi üzerinde farklı yönelimler oluşmaktadır. Medya ürünlerinin üretim sürecine katılanlarının üzerinde görünür ve görünmez nitelikte oluşan her türlü baskı, üretilen ürününün kitlesellik niteliği ve toplumsallaşma etkisi dolayısıyla siyasallaşma ve siyasal ekonominin yeniden üretimine farklı bir yön vermektedir (Bilgili, 2005: 112).

Toplumsal kurumlar içerisinde ekonomi gibi belirleyici olan kurumlardan biri de siyasettir. Siyaset, toplumda yaşayan insanlar arasında bir çatışma, bir mücadeledir. İnsanlar yaradıışları, sosyal ve ekonomik durumları bakımından değişik fikirlere ve değişik çıkarlara sahiptir. Aralarındaki düşünce, çıkar ve psikolojik eğilim farklılıklarından doğan çatışma siyasetin temelini oluşturmaktadır. Çatışmanın asıl konusu, toplumdaki değerlerin paylaşılmasıdır. Bu çatışmanın nedeni, toplumdaki değerlerin ve az olan kaynakların paylaşıma çabasıdır. Paylaşımı kolaylaştırmanın yoluysa iktidara sahip olmaktır (Kapani, 2001: 7). Siyasal sistem, bir ülkenin siyasi ortamını teşkil eden ilişki, süreç ve kurumların bütününü ifade etmektedir. Diğer bir ifadeyle siyasal sistem, bir toplumun kolektif amaçlarının siyasetle ilgili olanlarını belirleyen ve gerçekleştiren sosyal kurumlar bütünüdür (Yayla, 2005: 207). Siyasal sistem, toplum içinde yer alan ve kendi bünyesinde devlet ve hükümeti de barındıran bir yapıdır. Devlet, kolektif siyasi kararların uygulanmasıyla görevli bütün 
kamu kurumlarını, bakanları, yargıçları, milletvekillerini, bürokratları, asker rütbelileri ve polisleri bünyesinde toplayan organdır (Yayla, 2002: 7-8). iktidarsa kendi iradesinin egemen kılabilme, başkalarının davranışlarını denetleyebilme, bir şeyi yapmaya ya da yapmamaya zorlayabilme gücü olarak tanımlanabilir. Başka bir deyişle, iktidar karar alma ve alınan kararları uygulama, uygulatma gücünü içermektedir (Kışlalı, 1999: 18).

Çalışma kapsamında ele alınan medya ve siyaset kurumları, kamusal hizmet yapan, toplum tarafından görevlendirilen alternatifsiz bir sistem olarak görülmektedir. íki kurumun da çalışmalarını, toplum adına yürüttüğünü söylemek mümkündür. Kitleleri bilgilendirmeyi ve buna bağlı olarak yönlendirme merkezlerini içine alan medya ile bu fonksiyonları kendi doğasından ve biraz da sistemden alan siyaset arasında her zaman bir işbirliği ve bunun yanı sıra bir çatışma söz konusudur. Her iki güç de yönlendirme ve bilgilendirmenin kendi tekelinde olmasını tercih etmekte ve zaman zaman bunu paylaşımla elde etmektedir. Dolayısıyla medya ve siyaset, her zaman ve her durumda sürekli etkileşim ve iletişim içinde olmak zorundadır. Medyanın gerçekten haber verme ve kamuoyunu bilgilendirme fonksiyonu siyasetle ilişkisi bağlamında değerlendirilmelidir (Akdağ, 2020: 1173).

Medya ve siyaset ilişkisinin pratikte en çok gündeme gelen yönü medyanın hükümet yanlısı yayınlarıdır. Medyanın hükümet yanlısı yayın yapması, yeni bir durum olmayıp medya-iktidar ilişkilerinin genel özellikleriyle ilgili olmasına karşın savunuculuğun niteliklerini dönemin kendine özgü koşulları ve dinamikleri belirlemektedir. Her dönemin siyasal özelliklerine bağlı olarak basın-iktidar ilişkileri biçim almıs ve medyanın iktidar yanlısı yayın yapması özünde değişmese de dönemsel özelliklerin farklılı̆ı nedeniyle her dönem farklı isimlerle anılan ilişki biçimleri olarak ortaya çıkmıştır (Uzun, 2014: 129). Diğer bir ifadeyle siyasetin yönetme üzerine inşa edilmiş yapısı, medya ve siyaset arasındaki ilişkiyi de yönetme, kontrol etme süreçlerine taşımakta ve siyaset-medya ilişkisini bir mücadele süreci içerisine çekmektedir. Bu bağlamda medya örgütlenmelerinin, siyasal mekanizmaların ve ekonomik yapıların da dâhil olduğu karmaşık bir ilişkiler ağı ortaya çıkmaktadır. Siyaset kurumu ve medya örgütlenmeleri arasında siyasal iktidara yakınlık ve uzaklık olarak tanımlanabilecek nedenlerin, medya içeriği ve özellikle haber söylemi üzerinde etkili olduğunu söylemek mümkündür (Gölcü, 2009: 98).

Schudson’a (2002: 263-266) göre, medyayı siyasi kurumlar olarak düşünmek, haberlerin doğasındaki değişim olanaklarını göz ardı etmek anlamına gelmektedir. Medyanın siyaset kurumu olmasından ziyade belirtilen iki alan arasında yakın bir etkileşim bulunmaktadır. Medya, siyasi sonuçları (seçim sonuçlarını) etkilediği gibi yasama kararlarının kaderini, bürokratik çekişmeleri ve bireysel siyasi ilerleme veya başarısızlık da pay sahibi olabilmektedir. Bu noktada medyanın siyasi etkisinin doğasını ve kapsamını açıkığa kavuşturmak için birçok farklı bakış açısı bulunmaktadır. İlk olarak, medya faaliyetlerini etkileyen her ne olursa olsun, bunu bağımsız medya gücü hakkında çok farklı sonuçları yansıtacak şekilde uygulanabilir. Diğer bir ifadeyle medya, hükümet yetkilileri tarafından sağlanan bilgileri ileterek etki sahibi olabilir. Bu durumda medya tarafından değil, yetkililer tarafından bir etki başlatılır. İkinci olarak, medya, "bilgi, prestij ve kamusal meşruiyet" taşıma potansiyeli olan bir alandır/araçtır. Dolayısıyla medya bu güçleri kullanarak siyasiekonomik kurumların bir güç aracına dönüşebilir ama bir çerçeveleme yapmaz. Üçüncü olarak, medya, bilgiyi belirli bir şekilde çerçeveleyerek etki uygulayabilir. Medya etkisinin bu üçüncü biçimi, neredeyse her zaman öğrencilerin ve medyayı eleştirenlerin, bir tür medya yanlılı̆ını keşfetmeyi ve azaltmayı umarak incelediklerini düşündükleri süreci kapsamaktadır.

Christopherson ve Van Jaarsveld (2005: 90), medyanın siyasi ve ekonomik kurumların etki çerçevesinde kalmaması için kendi içerisindeki dönüşümü önemsemesi gerektiğini vurgulamaktadır. Christopherson ve Van Jaarsveld (2005: 90), toplum içerisindeki egemen güçlerin (siyasi ve ekonomik olarak güçlü olan kurumlar ve kişiler) medya içeriklerinden medya çalışanlarına kadar birçok noktayı etkilediğini söylemektedir. Bu kurumsal etkilerden kaynaklanan ulusal farklııkların, yaratıcı çalışanların kendi çalışma yöntemleri seçimleri ve performans standartlarına ilişkin kararlar üzerinde ne kadar kontrole sahip oldukları konusunda çıkarımları vardır. Ayrıca, hem medya işçilerinin hem de işverenlerinin üretim gerçekleştirirken karşı karşıya kaldıkları riskleri ve proje tabanlı bir endüstriyi sürdürmenin maliyetlerinin nasıl dağıtıldığı görmezden gelinemeyecek boyuttadır.

Mazzolenı ve Schulz’a (1999: 260-261) göre, birçok ülkede medyanın siyasi alana artmakta ve medyanın işlevleri siyasi- ekonomik kurumlar tarafından sınırlandırımaktadır. Diğer yandan birçok ülkedeki siyasi kurumların, genişleyen medya gücü karşısında işlevlerini sürdürdüğünü de atlamamak gerekmektedir. Siyaset, medyaya bağımlı olmakla birlikte aynı zamanda medyayı kontrol edebilme potansiyeli olan bir toplumsal dinamiktir. Özellikle siyasi liderliğin ve siyasi pratiğin aşırı medyatikleştirilmesi, tüketiciler ve seyirci olmaya zorlanan vatandaşlar ve yeni bilgi ve iletişim teknolojilerinin yol açtığı siyasi katıımın parçalanması, demokrasinin düzgün işleyişini sekteye uğratabilmektedir. 
Mansell $(2004: 99,103)$, geleneksel medyanın yeni iletişim teknolojileriyle ekonomik ve siyasi baskıları minimum seviyelere indirilebileceğini belirtmektedir. Diğer bir ifadeyle yeni medya ürün ve hizmetlerinin bolluğunu ve çeşitliliğini vurgulama ve bunlara gömülü olan ilişkili iktidar yapıları ve süreçlerine çok az önem vererek erişimi teşvik etmeye odaklanma konusunda çok önemli bir eğilim vardır. Yeni medya arzının kapsamı ve ölçeğinde ve hayatımızın dijital teknolojiler ve hizmetler tarafından yönlendirilme şekillerinde yadsınamaz derecede büyük değişiklikler bulunmaktadır. Dolayısıyla yeni medyanın ekonomi-politik boyutu, iktidar ve kurumların yapılarıyla olduğu kadar sembolik biçim, anlam ve eylemle de ilgili olmalıdır.

Medyanın/sosyal medyanın siyasi propagandayla olan ilişkisini inceleyen Köseoğlu ve Al’a (2014: 115) göre sosyal medyanın bir siyasal propaganda aracı olarak kullanımında dikkat çeken önemli bir nokta, günümüzde siyasal sistemin aktif aktörlerince kullanım yoğunluğudur. Neredeyse bütün siyasi partilerin ve parti alt oluşumlarının sosyal medyada aktif bir hesabı bulunmakta ve partiler bütün siyasi programlarını bu hesaplar üzerinden sürdürmektedir. Hatta siyasi partilerin halkla ilişkiler faaliyetlerinin önemli bir boyutu bu portallar üzerinden yürütülmektedir. Siyasi partiler; günlük faaliyet programlarını, siyasi fikirlerini, rakip partilerle olan çekişmelerini hep bu hesaplar üzerinden seçmen ya da güncel deyimle takipçilerine duyurmaktadır. Sosyal medyanın siyasal propagandada kullanılmasının en büyük avantajı artık siyasetin bir takım kaygılardan arınmış zengin bir azınlığın uğraşı olmaktan çıkmış olmasıdır.

Günümüzde medya, ekonomi ve siyaset arasındaki ilişki politika biliminin ana konularından biri olarak yerini almış bulunmaktadır (Kapani, 2001: 28). Toplumsal güçler siyasal iktidarı ele geçirmek ya da etkilemek için sürekli bir uğraş vermektedir. Siyasal iktidarı ele geçiren güçler, devleti kendi çıkarları ve dünya görüşleri yönünden değiştirmek olanağını da büyük ölçüde medya ile gerçekleşmektedir (Kışlalı, 1999: 106). Medya siyaset ilişkisi parçalanmış ve bütünlüğünden koparılmış, materyalist bir ahlak ile mutlaklaştııımış idealist ama işlerliğini kaybetmiş bir ahlak arasında sıkışmıştır. Pratik kaygılar günlük siyasal amaçlara ulaşmanın en ideal biçimlerine dönüşebilmek için materyalist tarzda da olsa mutlak etik değerler olma yolundadır. Mevcut durum siyasetin medya üzerindeki müdahaleleri nedeniyle medya tarafsız yayın yapamamış; bu da kamuoyu üzerinde medyaya karşı bir "güvensizlik" oluşumuna sebep olmuştur. Siyaset tarafından bazı gerçekler göz ardı edilmiş, kamuoyu medya haberlerinin doğruluğu konusunda algılama boşluğu yaşamaya mahkûm edilmiştir (Yılmaz, 2013: 250).

\section{Metodoloji}

Çalışmanın metodoloji kısmında yöntemle ilgili bilgiler açıklanmıştır. İ̧̧erik çözümlemesi yöntemi genel hatalarıyla tanımlanarak araştırma kapsamında kullanııma gerekçesi belirtilmiştir. Diğer yandan araştırmanın evren ve örneklem bilgileri, amacı ve önemi de yine metodoloji başlığı içerisinde açıklanmıştır.

\subsection{Yöntemin Tanımlanması}

İçerik analizi, iletişimin açık içeriğinin nesnel, sistematik ve nicel olarak tanımlanması için kullanılan bir araştırma tekniğidir (Berelson, 1952: 18). Diğer bir ifadeyle içerik analizi, metin içerisindeki belirli özellikleri sistematik ve nesnel olarak tanımlayarak çıkarımlar yapmayı sağlayan bir araştırma tekniğidir (Stone vd., 1966: 5). İçerik analizi, metinden geçerli çıkarımlar yapmak için bir dizi prosedür kullanan (Weber, 1990: 9) ve metinlerden (veya diğer anlamlı maddelerden) kullanım bağlamlarına ilişkin tekrarlanabilir ve geçerli çıkarımlar yapan bir araştırma yöntemidir (Krippendorff, 2013: 24). Içerik analizinin yapmaya çalıştığı çıkarımlar, bir şeyin (şiddet, kadınların olumsuz tasvirleri gibi) miktarını ölçmeye dayanmaktadır. Sonuç olarak, İçerik analizi, malzemenin belirli özelliklerini sistematik ve nesnel olarak tanımlayarak bir malzeme gövdesinden (genellikle sözlü) istenen bilgileri çıkarmak için kullanılan bir tekniktir. Böylece, diğer nitelikli araştırmacılar tarafından yeniden üretilebilecek tarafsız sonuçlar vermektedir (Berger, 1998: 23).

Kişiler günlük etkileşimlerinde sürekli olarak anlamı deşifre etmek ve iletişimi yorumlamaya çalışmaktadır. Nitel veri analizi, anlamla ilgilenmesi bakımından gündelik anlayışa benzemektedir. Ancak aynı zamanda günlük aktivitelerin de ötesine geçmektedir. Nitel veri analizinin her yöntemi, günlük anlayışın eksikliklerinin üstesinden gelmek için farkı bir yöntem sunmaktadır. İ̧erik analizinin bunu yapma şekli şu şekildedir: ilk olarak, metinde ilgi çeken tüm bu anlamları bir kodlama çerçevesinin kategorilerine çevirmek gerekmektedir; ikincisi, metnin ardışık bölümlerini bu kategorilere göre sınıflandırmayı sağlamaktadır. Bunun yapılma şekli, içerik analizinin üç önemli özelliğini vurgular: sistematik bir yöntemdir, esnektir ve verileri azaltmaktadır. Temel olarak içerik analizinin aşamaları; araştırma sorularına karar verilmesi, metin seçimi, kodlama cetveli oluşturma, metni kodlama birimlerine bölme, kodlama cetvelini deneme, değerlendirme, ana analiz ve bulguları yorumlama şeklindedir (Schreier, 2012:5-6). Schreier'in belirttiği gibi özellikle medya metinlerinin çözümlenmesinde nesnel, sistematik ve detaylı sonuçlara ulaşmayı sağlaması açısından bu çalışmada içerik analizi yönteminin kullanılması uygun görülmüştür. İçerik analiziyle gazete haberleri incelenmiş ve toplumsal yapıda karşılığı olduğu düşünülen birçok nokta görünür kılınmıştır. 


\subsection{Evren ve Örneklem}

Bu çalışmada, 1 Ocak-1 Şubat 2019 tarihleri arasında geleneksel yayıncılık yapan bir gazetenin² siyasi haberleri incelenmiştir. Bir aylık süre zarfında ekonomik verilerin kullanıldığı 28 adet siyasi haber tespit edilmiştir. Araştırmanın evrenini Türk yazııı basını oluşturmuştur. Örneklemini ise medya grubunun içinde yer alan, azımsanmayacak bir okuyucu kitlesi olan aynı zamanda siyasi haberlere ağırlık veren ve kamuoyunun oluşmasında etkili olan bir geleneksel gazete oluşturmaktadır. Diğer yandan ilgili gazetenin konu kapsamında ele alınan medya, siyaset ve ekonomi kavramları arasındaki ilişkileri daha net ortayı koyması öngörülmektedir. Çünkü ilgili gazete, siyasi-ideolojik duruşuyla belirtilen üç dinamiğin merkezinde yer almaktadır. Çalışmanın zamansal aralığı, 31 Mart 2019’ da gerçekleştirilen Türkiye yerel seçimleri öncesinde (1 Ocak ve 1 şubat tarihlerinde) siyasi haberlerdeki ekonomik verilerin iyice görünür olması sebebiyle tercih edilmiştir.

\subsection{Amaç ve Önem}

Çalışmanın temel amacı, medya, siyaset ve ekonomi kurumları arasındaki ilişkiyi incelemek ve siyasi haberlerde yer alan ekonomik unsurları tespit ederek, ekonomik verilerin siyasi haberler içerisinde nasıl konumlandırıldığını ortaya koymaktır. Siyasal gruplar, kendi değer yargılarını ve fikirlerini topluma aktarmak için medyayı bir araç olarak kullanmaktadır. Bu anlamda, medya ve siyaset yakın bir ilişki içerisinde olmakta ve medya içeriği siyasallaşmakta ve bazı medya kuruluşları siyasal bir kimliğe bürünmektedir. Bu süreçte, haber ve siyaset ilişkisinde, ekonomik menfaatler ortaya çıkmaktadır. Çalışma, siyaset ve medya ilişkisinin yanında, medyada çıkan siyasi haberlerdeki ekonomik ilişkileri de ortaya çıkarması açısından önemli olmaktadır.

\subsection{Verilerin Elde Edilmesi ve Kullanılan Testler}

Siyasi haberlerde yer alan ekonomik unsurları tespit etmek ve bu unsurları belirli bir sistematiğe dökerek nitel olarak yorumlayabilmek adına "içerik çözümlemesi yöntemi" kullanılmıştır. İçerik analizi için konunun amacına uygun bir kodlama cetveli oluşturulmuş ve belirlenen tarihlerde belirlenen haberler üzerinde bu kodlama cetveli uygulanmıştır. Kodlama cetveli oluşturulurken bir uzmandan yardım alınmıştır. Ekonomik verilerin siyasi haberlerde nasıl konumlandığını ortaya koymak adına "frekans analizi" yapılmıştır. Bu analizi yapmak için, veriler SPSS programı kullanılarak kodlanmıştır. SPSS'e kodlanan veriler betimsel analiz yöntemlerinden frekans ve geçerli yüzde kullanılarak yorumlanmıştır.

\section{Bulgular ve Yorumlar}

Bu bölüm içerisinde haberleri analiz edilen gazete örneğinde araştırmacılar tarafından belirlenen altı farklı tabloya ve bu tablolara ait yorumlara yer verilmiştir. Medya, siyaset ve ekonomi kurumları arasındaki etkileşim alanlarından biri olan haber metinlerine ait farklı çözümlemeler, çalışmanın teorik kısmında belirtilen ilişkileri destekler nitelikte verilerin elde edilmesini sağlamıştır. Bulgular genel olarak incelendiğinde ekonomik verilerin en çok "yolsuzluk" kavramıyla ve en fazla "haber içeriğinde" kullanıldığı görülmüştür. Siyasi haberlerde kullanılan ekonomik veriler, en çok "açıışlarda" dile getirilmiş ve en fazla Cumhurbaşkanı'nın açıklamalarında yer bulmuştur. Çalışmada elde edilen bulgulardan bir diğeriyse analiz edilen gazetedeki siyasi haberlerde ekonomik verilerin genellikle "olumlu" bir şekilde kullanılması olmuştur. Siyasi haberlerdeki ekonomik verilerin en çok "büyüme, kriz ve istihdam" kavramlarıyla ilişkilendirilmesi de bu çalışma kapsamında elde edilen bulgular arasındadır.

Tablo 1. Ekonomik Verilerin Kullanıldığı Haber Konuları

\begin{tabular}{lcccc}
\hline & Sayı & Yüzde & Geçerli Yüzde & Toplamlı Yüzde \\
\hline Yolsuzluk & 4 & 14,3 & 14,3 & 14,3 \\
\hline İşsizlik & 1 & 3,6 & 3,6 & 17,9 \\
\hline Ulaşım & 5 & 17,9 & 17,9 & 35,7 \\
\hline Sanayi & 4 & 14,3 & 14,3 & 50,0 \\
\hline İç Siyaset & 4 & 14,3 & 14,3 & 64,3 \\
\hline Uluslararası İlişkiler & 1 & 3,6 & 3,6 & 67,9 \\
\hline Sağlık & 3 & 10,7 & 10,7 & 78,6 \\
\hline
\end{tabular}

\footnotetext{
${ }^{2}$ Çalışma kapsamında analiz edilen medya aracı, dergi editörünün ve hakemlerinin bilgileri dâhilinde olan ulusal bir gazetedir.
} 


\begin{tabular}{lcccc}
\hline Tarım & 2 & 7,1 & 7,1 & 85,7 \\
\hline Güvenlik & 2 & 7,1 & 7,1 & 92,9 \\
\hline Turizm & 1 & 3,6 & 3,6 & 96,4 \\
\hline Konut Sektörü & 1 & 3,6 & 3,6 & 100,0 \\
\hline Toplam & 28 & 100,0 & 100,0 &
\end{tabular}

Siyaset haberlerindeki ekonomik verilerin sunulduğu konuları incelediğimizde \%17,9'lik oranıyla Ulaşım sektörünün birinci sırada yer almaktadır. Ulaşım sektörünü \%14,3'lük oranlarıyla Yolsuzluk, Sanayi ve íç Siyasetle ilgili konular izlemiştir. Bu konuları \%10,7 ile Sağlık, \%7,1'lik oranlarıyla Tarım ve Güvenlik, \%3,6'lık oranlarıyla da Işsizlik, Turizm ve Konut Sektörü takip etmiştir. Tablo 1'de sunulan bulgular, siyasi içerikli haber metinlerindeki temel ekonomik parametrelere işaret etmesi açısından önem arz etmektedir. Diğer bir ifadeyle toplumsal alandaki birçok ekonomik konu ve kavram, analiz edilen gazetedeki haber metinlerinde karşımıza çıkmaktadır.

Tablo 2. Ekonomik Verilerin Haberde Yer Aldığı Bölümler

\begin{tabular}{lcccc}
\hline & Sayı & Yüzde & Geçerli Yüzde & Toplamlı Yüzde \\
\hline Ana Başlık & 1 & 3,6 & 3,6 & 3,6 \\
\hline Alt Başlık & 7 & 25,0 & 25,0 & 28,6 \\
\hline Haber İçeriği & 19 & 67,9 & 67,9 & 96,4 \\
\hline Fotoğraf Alt Yazısı & 1 & 3,6 & 3,6 & 100,0 \\
\hline Toplam & 28 & 100,0 & 100,0 & \\
\hline
\end{tabular}

Illgili gazetede yer alan siyaset haberleri incelendiğinde içeriğinde ekonomik veriler barındıran 28 adet haberin yayınlandığı görülmüştür. Tablo 2’ye göre haberlerde ekonomik verilerin en çok kullanıldığı bölüm \% 67,9 ile Haber İçeriği olmuştur. Haber içeriğini,\%25 ile Alt Başlık \%3,6 oranlarıyla da Başlık ve Fotoğraf Alt Yazısı bölümleri takip etmiştir. Habercilik açısından okurun en fazla ilgi duyması/okuması en kolay olan kısım Ana Başık iken analiz edilen siyaset haberlerinde ekonomik verilerin en fazla Haber İ̧̧eriğinde kullanılmış olması ilginç bir bulgu olarak karşımıza çıkmaktadır. Elde edilen bu bulgu, siyasi haberlerdeki ekonomik verilerin Ana Başlıkta birkaç kelimeyle sınırlı tutulmak yerine haber içeriğinde detaylı bir şekilde sunulduğunu göstermektedir. Haber içeriğinde detaylandırılan/kullanılan ekonomik veriler, Alt Başlıkla desteklenmiştir.

Tablo 3. Ekonomik Verilerin Sunulduğu Mekanlar

\begin{tabular}{lcccc}
\hline & Sayı & Yüzde & Geçerli Yüzde & Topl mlı Yüzde \\
\hline Açılışlar & 11 & 39,3 & 39,3 & 39,3 \\
\hline Mitingler & 7 & 25,0 & 25,0 & 64,3 \\
\hline Forumlar & 5 & 17,9 & 17,9 & 82,1 \\
\hline Parti Grup Toplantıları & 2 & 7,1 & 7,1 & 89,3 \\
\hline Dış Ülke Gezileri & 3 & 10,7 & 10,7 & 100,0 \\
\hline Toplam & 28 & 100,0 & 100,0 &
\end{tabular}

Siyaset haberlerinde kullanılan ekonomik verilerin en fazla \%39,3 ile Açılışlarda kullanıldığı görülmektedir. Açılışları, \%25'lik oranıyla Mitingler, \%17,9 oranıyla Forumlar, \%10,7 Dış Ülkelere Yapılan Geziler ve \%7,1 oranıyla da Parti Grup Toplantıları izlemiştir. Tablo 3 bulgularına göre ilk sırada bulunan açılışların önemli bir kısmı online/dijital olarak gerçekleştirilmiştir. Kullanılan araç ve/veya ortamın farklılaşmasına (geleneksel veya yeni medya) rağmen açılışlar, siyasi haberlerdeki ekonomik verilerin en çok kullandığı alanlar arasında ilk sırada bulunmaktadır.

Tablo 4. Ekonomik Verileri Sunan Kaynak

\begin{tabular}{lcccc} 
& Sayı & Yüzde & Geçerli Yüzde & Toplamlı Yüzde \\
\hline Cumhurbaşkanı & 13 & 46,6 & 46,6 & 46,4 \\
\hline Muhalefet Parti Başkanları & 6 & 21,4 & 21,4 & 67,9 \\
\hline Milletvekilleri & 1 & 3,6 & 3,6 & 71,4 \\
\hline
\end{tabular}




\begin{tabular}{lcccc}
\hline Bakanlar & 8 & 28,6 & 28,6 & 100,0 \\
\hline Toplam & 28 & 100,0 & 100,0 & \\
\hline
\end{tabular}

Ekonomik verileri siyaset haberlerine taşıyan kaynaklar incelendiğinde Cumhurbaşkanının, \%46,4'lük oranıyla birinci sırada yer aldığı görülmektedir. Cumhurbaşkanını, \%28,6'lık oranıyla Bakanlar, \%21,4'lük oranıyla Muhalif Parti Başkanları, \%3,6'lık oranıyla da Milletvekilleri takip etmiştir. Tablo 4 bulguları, siyaset alanındaki hiyerarşik düzenin siyaset haberlerindeki ekonomik verilerin yer aldığı haber metinlerinde de değişmediğini göstermektedir. Diğer bir ifadeyle ülkenin birinci dereceden yönetim sorumlusu olan Cumhurbaşkanı, haberlerde birinci sırada kaynak olarak yer almaktadır.

Tablo 5. Ekonomik Verilerin Kullanıldığı Siyasi Haberlerin Ön Plana Çıkan Söylemleri

\begin{tabular}{lcccc}
\hline & Sayı & Yüzde & Geçerli Yüzde & Toplamlı Yüzde \\
\hline Büyüme & 7 & 25,0 & 25,0 & 75,0 \\
\hline Kriz & 5 & 17,9 & 17,9 & 35,7 \\
\hline İstihdam & 4 & 14,3 & 14,3 & 50,0 \\
\hline Gelişme & 4 & 14,3 & 14,3 & 85,7 \\
\hline Atılım & 3 & 10,7 & 10,7 & 14,3 \\
\hline Çağ Atlama & 2 & 7,1 & 7,1 & 82,1 \\
\hline Pazarlık & 1 & 3,6 & 3,6 & 3,6 \\
\hline Rüya & 1 & 3,6 & 3,6 & 100,0 \\
\hline İnşa Etme & 1 & 3,6 & 3,6 & \\
\hline Toplam & 28 & 100,0 & 100,0 & \\
\hline
\end{tabular}

Ekonomik verilerin kullanıldığı siyaset haberlerinin söyleminde ön plana çıkan unsurlar incelendiğinde, birinci sırada \%25 oranıyla Büyüme unsurunun yer aldığı görülmektedir. Tablo 5 bulgularına göre, Büyüme unsurunu \%17,9 oranıyla Kriz ve \%14,3'lük oranlarıyla İstihdam ve Gelişme unsurları takip etmektedir. Diğer yandan \%10,7 oranıyla Atııım, \% 7,1 ile Çağ Atlama ve \%3,6'lık oranlarıyla da Rüya ve İnşa Etme unsuları da ekonomik verilerin kullanıldığı siyaset haberlerinin söylemlerinde kullanılan unsurlar olmuştur.

Tablo 6. Ekonomik Verilerin Siyasi Haberlerin İçeriğine Etkisi

\begin{tabular}{lcccc}
\hline & Sayı & Yüzde & Geçerli Yüzde & Toplamlı Yüzde \\
\hline Olumlu & 22 & 78,6 & 78,6 & 78,6 \\
\hline Olumsuz & 6 & 21,4 & 21,4 & 100,0 \\
\hline Toplam & 28 & 100,0 & 100,0 &
\end{tabular}

Ekonomik verilerin kullanıldığı siyaset haberlerinde, ekonomik verilerin haber içeriğine etkisinin yönünün çoğunlukla \%78,6'lık oranıyla olumlu olduğu görülmektedir. Ekonomik verilerin siyaset haberlerinin içeriğine olumsuz etkisinin oranı ise \%21,4'tür. Tablo 6 bulgularına göre, analiz edilen gazetedeki her 5 haberin $4^{\prime}$ ünde ekonomik veriler siyasi içerikleri destelemek/güçlendirmek için kullanılmıştır.

\section{Sonuç ve Tartışma}

Çalışma kapsamında incelenen gazetedeki siyasi haberlerde siyaset, ekonomi ve medya arasındaki etkileşim açıkça görülmektedir. Ekonomik verilerin kullanıldığı haberler incelendiğinde, en fazla haberin iktidar koalisyonuna ait olduğu görülmektedir. Muhalif partilerin ekonomi verileri içeren siyasi haberleri oldukça az sayıda kullandığı görülmektedir. İktidar koalisyonu, ekonomik verileri genelde olumlu muhalefet partileriyse olumsuz yönde kullanmıştır. Elde edilen bulgular açıkça ortaya koymaktadır ki; medya, işin doğası gereği siyaset, ekonomi ve diğer toplumsal kurumlarla etkileşim halindedir. Bu noktada siyasi haberlerdeki ekonomik verilerin toplumu yakından ilgilendiren "yolsuzluk, işsizlik, ulaşım, uluslararası ilişkiler ve sağıı" gibi kavramlar/dinamikler çerçevesinde inşa edildiği görülmüştür. 
Toplum, kendini yönetenlerin yaptıklarından haber almak, siyasetçiler ise yaptıklarını duyurmak için medyayı kullanmaktadır (Arabacı, 2004: 105). Medya bazen siyaset bazen de sermaye endeksli etkilerin odağında olmaktadır. Bu durum medyanın temel işlevi olan haber ve bilgilendirme ile kamuoyunun sağlıklı oluşumuna katkıda bulunmak yerine kendi oluşturduğu dünyanın topluma enjekte edilmesini sağlamaya çalışarak kamuoyunun sağlıklı gelişimini zaafa uğratmıştır (Ceylan, 2012: 51). Medya kurumu, biri daha uzak ve güçlü olanı temsil eden temel kurumlar ve toplumun güç merkezleri, diğeri ise yakında bulunan şeyleri deneyimi ve insanı gösteren iki eğri arasındaki alana yerleştirilmiştir (McQuail, 2000: 55). Medya sektörü donanımı, alt yapısı, istihdam potansiyeli, tüm üretim ve tüketim süreçleri ile özünde ticari-sanayi bir etkinliktir. Dolayısıyla medyanın toplumsal yaşamda varoluş ve kendisini yeniden üretme biçimi, kendisinin de yer aldığı genel toplumsal sistem içerisinde; bu bağlamı oluşturan toplumsal-siyasal-ekonomik güç ilişkilerinin eklemlenmesi çerçevesinde oluşmaktadır (Kaya, 1999: 23). Kitle iletişim araçlarının görevi haber ve bilgi vermek suretiyle kamuoyunu bilgilendirmek, kamuoyunu bilgilendirerek, kamuoyunun serbestçe oluşmasına katkı sağlamak iken basın kamuoyunu bilgilendirmek yerine belirli bir doğrultuda tavır almaya zorlamaktadır. Bunun temelinde ekonomik politik kurumların basın üzerinde yaptırım gücüne sahip olması yatmaktadır (Işık, 2005: 86). Siyasi haberlerdeki ekonomik veriler, toplumsal sistem içerisinde en çok açוlış ve miting gibi siyasi mekânlarda dile getirilmiştir. Ayrıca ilgili gazetenin ekonomi-politik duruşu iktidar koalisyonunun gerçekliğiyle örtüştüğü için bu gazetede yer alan haberlerde ekonomik verilerin genel olarak siyasal koalisyona artı sağlayacak şekilde kullanılması şaşırtıcı olmayan bir sonuç olarak karşımıza çıkmaktadır.

Çalışma bulgularında ekonomik verilerin en fazla "haber içeriğinde" kullanıldığı ve haberde sunulmak istenen mesajların, ekonomik verilerle desteklendiğini göstermektedir. Ekonomik verileri siyasi haberlere en çok taşıyan kişi Cumhurbaşkanı olmuştur. Cumhurbaşkanını, bakanlar, muhalif parti başkanları, milletvekilleri takip etmiştir. Ekonomik verileri siyasi haberlerde kullanan isimler bunu en fazla Açılışlarda gerçekleştirmişlerdir. Açılışları, mitingler, forumlar, dış ülkelere yapılan geziler ve parti grup toplantıları izlemiştir. Iktidar partisi, ekonomik verilerin kullandığı siyaset haberlerinin söylemini büyüme, istihdam ve gelişme konularıyla ön plana çıkarmış, muhalif partilerin ise krize neden olabilecek, ülke için olumsuz olaylara neden olabilecek sıkıntılı durumları ekonomik verilerle ilişkilendirdiği görülmüştür. Altchull'a göre bütün basın sistemlerinde, haber medyası politik ve ekonomik gücün sahibi insanların temsilcisidir. Gazeteler, dergiler ve elektronik yayın araçları bağımsız güce sahip olma potansiyeline rağmen bağımsız değildirler ve haber medyasının içeriği daima basının masraflarını karşılayanların çıkarlarına uygundur (Severin ve Tankard, 1994: 507508). Kitle iletişimin ekonomik politik görüşü medyayı sivil topluma özgü, yani öncelikle ekonomik bir fenomen olarak ele almaktadır. Medyanın hem meta üretim ve değiş tokuşunda artı değer yaratıcısı olarak doğrudan bir rolü olduğuna, hem de reklamcılık yoluyla meta üretiminin diğer kesimlerinde artı değer üreterek dolaylı bir rolü olduğuna inanmaktadır. Günümüzde de ekonomik politik kurumların medyadaki uzantılarını görmemiz mümkündür. Çünkü medya, hükümetlerin, büyük şirketlerin ve profesyonel bilgi imparatorlarının görüşlerini kelime kelimesine tekrar etmekten öteye geçememekte (Keane, 1999: 79, 163) ve medyanın örgütlenme şekli, belirlemiş olduğu politikalar, ekonomik nedenlerden kaynaklanan ilişkiler ve daha birçok unsur, medya içeriğinin belirlenmesinde etkili olmaktadır (Terkan, 2005: 564).

Toplumsal kurumlar insan yaşamının zorunlu olarak beraberinde getirdiği kurumlardır ve her biri ayrı ihtiyaçlara cevap vermektedir. Bu kurumlar, ayrı yapılarda olmakla birlikte birbirlerini etkilemekte ve birbirlerinden etkilenmektedir. Siyaset, ekonomi ve medya kurumları toplumun önemli kurumları arasında yer almaktadır ve aralarında zorunlu olarak bulunan ve koparılamaz bir bağ bulunmaktadır. Siyaset, medya üzerinden söylemlerini kamuoyuna duyururken, medya da siyasi alanda etkin olmak adına siyasi alanla iyi ilişkiler kurmaya özen göstermektedir. Siyaset ve medya arasındaki ilişkinin diğer bir boyutu da ekonomik nedenlere dayanmaktadır. Medya kuruluşları birer ekonomik kuruluş olarak örgütlendiğinden siyasi alanla ilişkilerini bozmamaya gayret etmekte ve bunun karşılığında da ekonomik destek görmektedirler.

Belirtilenler doğrultusunda konuyla ilgili yapılacak sonraki çalışmalara yönelik bazı öneriler sunmak mümkündür. Medyanın ekonomi ve siyaset alanlarıyla olan ilişkisinin ayrı ayrı ele alınması daha detaylı bulgulara ulaşılmasını sağlayacaktır. Konuyla ilgili sonraki çalışmalarda daha fazla sayıda gazete eklenebilir. Diğer yandan gazetelere, medya alanının diğer bölümleri/araçları olan radyo, televizyon ve sinema da dâhil edilerek medya alanı ekonomi-politik açıdan karşılaştırılabilir. Son olarak konuyla ilgili gazeteler açısından yapılacak çalışmalarda geleneksel ve yeni medya içerisinde yayıncılık yapan haber kuruluşlarına odaklanılarak teknolojik tabanlı analizler görünür kılınabilir. 


\section{Kaynakça}

Akdağ, M. (2020). Medya siyaset etkileşimi bağlamında Türkiye'de siyasetin medya alanındaki düzenlemeleri üzerine bir inceleme. Erciyes Iletişim Dergisi, 7(2), 1173-1197.

Altınok, S. (2002). iktisat bilimine giriş. Konya: Selçuk Üniversitesi Yayınları.

Arabacı, C. (2004). Basın ve siyaset üzerine. Der. M. Işık. Medyada yeni yaklaşımlar. Konya: Eğitim Kitapevi.

Arslan, A. (2006). Medya-politika ilişkisi üzerine sosyolojik bir değerlendirme. Uluslararası Insan Bilimleri Dergisi, (5), 19.

Aslan, K. (2002). Haberin yol haritası. İstanbul: Anahtar Kitaplar Yayınevi.

Berelson, B. (1952). Content analysis in communication research. New York: Hafner Publications.

Berger, A. A. (1998). Media research techniques. Thousand Oaks, CA: Sage Publications.

Bilgili, C. (2005). Medya(nın) ekonomisi ve medya ürününe etki biçimleri. Iletişim Dergisi, 3, 95-112.

Bülbül, R. (2001). Haberin anotomsi ve temel yaklaşımlar. Ankara: Nobel Yayınları.

Ceylan, Y. (2012). Toplumsal değerler ve medya etiği. Dicle Üniversitesi Sosyal Bilimler Enstitüsü Dergisi, 4(7), 45-58.

Chomsky, N. (1993) Medya gerçeği. Çev. A. Yılmaz. İstanbul: Tümzamanlar Yayıncılık.

Christopherson, S. \& Van Jaarsveld, D. (2005). New media after the dot.com büst. International Journal of Cultural Policy, 11(1): 77-93.

Curran, J., Gurevitch, M., \& Woollacott, J. (2005). The study of the media: Theoretical approaches. Culture, society and the media. Routledge. 15-34.

Demirci R. Arıkan, R. \& Erdoğan B. (2001). Genel ekonomi. Ankara: Gazi Kitapevi.

Eski, H. (1995). Ekonomiye giriş. İzmir: Dokuz Eylül Üniversitesi Mühendislik Fakültesi Yayınları.

Gezgin, S. (2006). Medya ve demokrasi. Alman-Türk Gazeteciler Semineri, 165-176.

Gölcü, A. (2009). Haber söyleminde medya-siyaset ilişkisi: 29 Mart 2009 yerel seçimleri. Gazi Üniversitesi Iletişim Fakültesi Iletişim Kuram ve Araştırma Dergisi, 29, 81-101.

Gürcan, H. I. \& Yüksel, E. (2005). Haber toplama ve yazma. Konya: Tablet Yayınları.

ışık, M. (2005). Türkiye'deki iletişim sisteminin medya siyaset ilişkilerine yansımaları. Der Z. Damlapınar. Medya ve siyaset ilişkileri üzerine. Ankara: Turhan Kitabevi.

İçel, K. (1990). Kitle haberleşme hukuku. İstanbul: Beta Yayınları.

Kapani, M. (2001). Politika bilimine giriş. Ankara: Bilgi Yayınevi.

Kaya, R. (1999). Medya, toplum, siyaset. Ed. K. Alemdar. Medya gücü ve demokratik kurumlar. İstanbul: Afa Yayınları, 23-33.

Keane, J. (1994). Medya ve demokrasi. Çev. H. Şahin. İstanbul: Ayrıntı Yayınları.

Kışlalı, A.T. (1999). Siyaset bilimi. Ankara: Imge Kitapevi.

Köseoğlu, Y. \& Al, H. (2014). Bir siyasal propaganda aracı olarak sosyal medya. Akademik Incelemeler Dergisi, 8(3) , 103125.

Krippendorff, K. (2013). Content analysis: An introduction to its methodology. Los Angeles, CA: Sage Publications.

Mansell R. (2004). Political economy, power and new media. New Media \& Society. 6(1): 96-105.

Mazzoleni, G. \& Schulz W. (1999) Mediatization of politics: a challenge for democracy?, Political Communication, 16(3): 247-261.

McQuail, D. (1994). Kitle iletişim kuramı. Çev. A. H. Yüksel. Eskişehir: Kibele Sanat Merkezi.

Necla, M. (2008). Medya çalışmaları: Medya pedagojisi ve küresel iletişim. Altkitap Yayınevi. 
Özçağlayan, M. (2014). Gazetelerin gelişimi ve gazeteciliğin geleceği (Yeni teknolojiler ve medya ekonomisi açısından genel bir değerlendirme). Marmara iletişim Dergisi, 13(13), 131-159.

Özgüven, A. (1975). Iktisat ilmine giriş. İstanbul: İstanbul Üniversitesi Yayınları.

Ramonet, I. (2000). Medyanın zorbalığı. Çev. A. Derman. İstanbul: Om İletişim Yayınları.

Schreier, M. (2012). Qualitative Cotent Analysis in Pratice. London: Sage Publications.

Schudson, M. (2002). The news media as political institutions. Annual Review of Political Science, 5(1), 249-269.

Severin, W.J. \& Tankard, J.W. (1994). Iletişim kuramları. Çev. A. A. Bir \& S. Sever. Eskişehir: Kibele Sanat Merkezi.

Stone, Philip J., Dunphy, D. C., Smith, M. S., ve Ogilvie, D. M. (1966). The general inquirer: A computer approach to content analysis. Cambridge: MIT Press.

Şahin H. (1997). Iktisada giriş. Bursa: Ezgi Kitapevi.

Şimşek S. \& Aydın, K. (2002). iktisat bilimine giriş. İstanbul: Değişim Yayınları.

Şimşek, S. (2009) Medya-siyaset-iktidar üçgeninde medya gerçeği. Selçuk iletişim Dergisi, 6(1), 124-143.

Terkan, B. (2005). Gündem belirleme. Konya: Tablet Yayınları.

Tokgöz, 0. (2000). Temel gazetecilik. Ankara: Imge Kitapevi.

Turan, E. (1994). Medyanın siyasal hayata etkileri. İstanbul: Irfan Yayıncılık.

Uzun, R. (2014). Medya-siyaset ilişkileri: Türkiye'de savunucu gazetecilik olgusunun incelenmesi. Iletişim Kuram ve Araştırma Dergisi, (39). 129-149.

Ülgen, G. (2002). Iktisat bilimine giriş. İstanbul: Der Yayınları.

Ünlüönen, K. \& Tayfun, A. (2005). Ekonomi. İstanbul: Nobel Yayınları.

Ünlüönen, K. \& Tayfun, A. (2011). Ekonomiye girişs. İstanbul: Nobel Yayınları.

Weber, R. P. (1990). Basic content analysis. Newbury Park, CA: Sage Publications.

Yaşın, C. (2013). Medya ve siyaset. Ed. Ö. Özer. Medya, siyaset, kültür. Eskişehir: Anadolu Üniversitesi Yayınları.

Yayla, A. (2002). Siyaset teorisine giriş. Ankara: Liberte Yayınları.

Yayla, A. (2005). Siyasi düşünceler sözlüğ̈̈. Ankara: Adres Yayınları.

Yılmaz, M. (2013). Medya ve siyaset ilişkilerinin kamuoyu üzerindeki etkileri: KKTC örneği. İnsan ve Toplum Bilimleri Araştırmaları Dergisi, 2(2), 230-252.

Yiğitbaşı, Ş. \& Atabey, N.A. (2001). Iktisada giriş, Konya: Selçuk Üniversitesi Vakfı Yayınları.

Yüksel, E. (2004). Medya güvenlik kurulu, Eskişehir: Anadolu Üniversitesi Iletişim Bilimleri Fakültesi Yayınları. 